\title{
Consumer Attitude towards Automobile Lubricants: A Case Study of PSO Lubricants
}

\author{
Salman Zakir \\ Dr. Fouzia Naeem Khan
}

\begin{abstract}
Consumers look for products to solve their immediate problems or perhaps to be a habitual buyer of the same product and so on. It becomes quite essential for organizations to understand a consumer behaviour and attitude towards a particular product or service. The insights gained through these kinds of research help organizations customize or augment their offering as per consumer's needs. In Pakistan, Diesel engine vehicles play an important role in the transportation fraternity of the Country. Heavy Duty Vehicles travel through different climate, road, temperatures, dusty areas and weather conditions. In order to save an engine from these external factors, Engine Oils play a key role. This study explores the consumer attitude towards buying a particular lubricant. A sample of 120 Diesel Engine Vehicles was conducted through a questionnaire which revolves around a few basic attributes that add to consumer purchase decision. PSO being the largest Oil Marketing Company having a huge retail network is still unable to grab a good market share during the past few years. This study carries significance in finding out the reasons behind PSO's low market share and identifies key areas that drive a consumer towards making a lubricant purchase.
\end{abstract}

Keywords: Consumer Behaviour, Attitudes, Oil Marketing Companies, Post Purchase Behaviour.

\section{Introduction}

\section{Background of the Study}

The overall lubricants sector in Pakistan grew by $5.3 \%$ in $2007-08$ as compared to 2006 07 (Pak Oil Report, 2007-08). Shell Pakistan Limited was the leading brand with $28.7 \%$ of market share followed by Pakistan State Oil and Chevron Pakistan Limited with $16.8 \%$ and $16.2 \%$ market share respectively. Lubricants sector is expected to remain de-regulated therefore, inviting more competition. However, to gain market leadership, strong brand positioning in targeted market segment (Diesel Engine Oil, Passenger Car, and Motorist Oil) is the key success factor (Pak oil report, 2007-08).

The sales for lubricants registered a decline of $10.28 \%$ at $184,122 \mathrm{M}$ Tons in FY08-09 as against 206,452 M Tons in the previous corresponding period. Heavy Duty Engine Oil (HDEO) and Industrial Oil are the top two selling lubricant varieties which jointly contribute for around $65 \%$ of the total lubricant sales. The off take for HDEO and Industrial Oil are

Salman Zakir is a Corporate Communications Executive at Pak-Arab Refinery Ltd. (PARCO)

Dr. Fouzia Naeem Khan is Dean of Social of and Media Sciences at SZABIST, Karachi, fouzia@szabist.edu.pk

Journal of Independent Studies and Research - MSSE

Volume 9

Number 1

January $2011 \mid 31$ 
dependent upon the magnitude of economic activity in the country which remained under pressure during the period under review due to which sales for HDEO and Industrial Oil witnessed a decrease of $13.19 \%$ and $15.29 \%$, respectively (Pak Oil report, 2008-09).During FY08-09, Shell Pakistan Limited (SPL) again came out as the largest selling lubricant brand with a market share of $29 \%$ followed by Chevron Pakistan Limited (CPL) with $16.17 \%$ and Pakistan State Oil (PSO) at $14.12 \%$ respectively. PSO, despite having an edge of the largest distribution network in the country, is losing its market share to its competitors. Lubricant sales for PSO totaled to 25,998 M Tons in FY08-09 which was 25.28\% lower on YoY basis compared to previous corresponding year (Pak oil report, 2008-09).

The automobile industry is moving at a rapid pace whereby increasing the number of vehicles on roads which includes all the four wheelers, three wheelers and two wheelers. These vehicles travel either within the city, while others travel even outside the city on a regular basis. At night, one can easily point out the heavy vehicles, ranging from car carriers to oil tankers, container movers, trucks and busses, all charged by a heavy duty diesel engine on roads. These vehicles cover long distances at different times with different weather conditions. In this regard, the engine is not only charged with the fuels, but automobile engine lubricants play a vital role in keeping the engine clean and perform better and provide greater mileage as well as increasing the life of the engine.

Every engine has a different requirement for lubricants; some require oil change at approximately $2,000 \mathrm{Km}$ while some at almost 6,000 to $7,000 \mathrm{Kms}$. It all depends upon the engine, the type, classification and many other conditions which may include the climate, road conditions, area where the vehicle is driven etc. These factors must be taken into account to determine as to how much time is required to change the engine oil.

The petroleum industry consists of many players of which Oil Marketing has a few well known players like Pakistan State Oil (PSO), Shell, Chevron, TOTAL PARCO Pakistan Ltd., who are in the business of marketing petroleum products through their retail network. They are also involved in marketing their own lubricant brands.

These companies put as much efforts they can by selling their brand of lubricants through their retail network, distributors or often called as high street sales and various other branding, marketing, advertisement and promotional activities.

\section{Consumer Behaviour, Attitude, Marketing Strategies: An Overview}

\section{Consumer Behaviour}

Consumer attitude towards a particular product has always been a point of major concern for almost every single firm. As organizations diversify their operations and increase their current product lines, it becomes even more essential for them to remain in close contact with the needs, beliefs, attitudes and perceptions of their customers and consumers. These close insights help them direct their future strategies.

Consumer Behaviour is all about understanding of how and why consumers purchase (or don't purchase) products and services. A knowledge of consumer behaviour is 
relevant to all types of enterprises - business firms (e.g. Unilever), non-profit organizations (e.g. SIUT) and government agencies involved in regulating marketing activities. Understanding consumer behaviour has a further function. It is also essential for appreciating how various societies' function, as consumption is an important activity in all cultures (Neal Quester Hawkins, 2002).

\section{Consumer Attitudes}

Attitudes represent what we like and dislike. Usually we do the things that we like to do while avoiding things that are disliked. If you don't like seafood, then it's unlikely that you intend to eat it. On the other hand, if you really do like seafood, you probably intend to consume it at some point in the future (Blackwell, et al., 2007).

Holding a favorable attitude towards a product is almost always an essential prerequisite in order for consumers to hold a favorable purchase or consumption intention. If consumers don't like a product, they'll take their business elsewhere. At the same time, however, favorable attitudes towards a product do not automatically translate into favorable purchase intentions. A consumer may like one brand but intend to buy another brand that is liked even more. For this reason, attitudes are sometimes measured in the form of preferences. Preferences represent attitudes towards one object in relation to another. For example, which Cola do you prefer, Coke or Pepsi? (Blackwell, et al., 2007).

Just because consumers prefer one product over its competitors still doesn't mean that they intend to buy the preferred product. You can prefer a Jaguar car without intending to buy one. Maybe you don't need a new car. Maybe you do but you can't afford a Jaguar's price. And maybe you can afford it but refuse to spend that much money on a car. The basic point is that having a favorable attitude towards a product is not the same as having a favorable attitude towards buying or consuming the product (Blackwell, et al., 2007).

\section{Consumer Behavior and Marketing Strategy}

Top executives in large multinational companies are aware of the contribution that an understanding of consumer behavior can make to the long term success of their company's product. Indeed, understanding and therefore, learning to anticipate consumer behavior is the key to planning and managing in today's ever changing marketing environment. In operational terms, gaining this understanding involves a continuous process whereby marketing researchers talk to hundreds of consumers to find out, among other things:

- What consumers think of a company's products and those of competitors?

- What they think of possible improvements in these products?

- How they use these products?

- What attitudes they have about these products and related advertising? 
- What they feel about their 'roles' in the family and society?

- What their hopes and dreams are for themselves and their families?

To survive in a competitive environment, an organization must provide target customers with more value than its competitors. Customer value is the difference between all the benefits derived from the total product and all the costs of acquiring these benefits. Providing superior customer value requires the organization to anticipate and react to customer needs faster and better than its competitors (Neal Quester Hawkins, 2002).

\section{A Simple Model of Consumer Decision Making}

This model presents an overview of the consumer decision making that reflects cognitive (i.e., problem-solving) consumer and to some degree, the emotional consumer. It addresses as to why does a consumer buys and what influences his/her decisions. The model has three major components: input, process and output (Schiffman \& Kanuk, 1999).

\section{Input}

The input component of our consumer decision-making model draws on external influences that serve as sources of information about a particular product and influence in consumer's product-related values, attitudes and behaviour. Chief among these inputs factors are the marketing mix activities of organizations that attempt to communicate the benefits of their products and services (Schiffman \& Kanuk, 1999).

\section{Process}

The process component of the model is concerned with how consumers make decisions. The psychological field represents the internal influences (motivation, perception, learning, personality and attitudes) that affect consumers' decision-making processes. The recognition of need is likely to occur when a consumer is faced with a problem. Pre-purchase search begins when a consumer perceives a need that might be satisfied by the purchase and consumption of a product. The recollection of past experiences might provide the consumer with adequate information to make the present choice (Schiffman \& Kanuk, 1999).

When evaluating potential alternatives, consumers tend to use two types of information, a list of brands from which they plan to make their selection and the criteria they will use to evaluate each brand (Schiffman, Kanuk, 1999).

\section{Output}

The output portion of the consumer decision-making model concerns two closely associated kinds of post-decision activity, purchase behaviour and post-purchase evaluation. The objective of both activities is to increase the consumer's satisfaction with his or her purchase. Consumers make three types of purchases; trial purchases, 
repeat purchases, and long-term commitment purchases. When a consumer purchases a product for the first time and buys a smaller quantity than usual, this purchase would be concerned a trial. Repeat purchase behaviour is closely related to the concept of brand loyalty, which most firms try to encourage, because it contributes to greater stability in the marketplace (Schiffman, Kank, 1999).

\section{Other Models to Measure Consumer Attitude}

Two major paradigms have provided much of the impetus for the study of consumer behavior. Choices among alternative brands, products, or services are in many ways no different from other kinds of decisions, and the methods of behavioral decision theory have thus proven valuable to the study of consumer behavior. Multi-attribute decision models emphasize the importance of expected values derived from a product's perceived attributes. However, as in other kinds of decisions, judgments underlying consumer choices are found to deviate in systematic ways from normative prescriptions (Ajzen, I.,2008).

One limitation of the revealed preferences approach adopted in work on multi-attribute decisions is that it provides no direct information about consumers' beliefs and attitudes regarding real-life products or services. A more fruitful approach in this regard is found in the expectancy-value model of attitude. In work with this model, accessible beliefs about a product are elicited in a free-response format and attitudes toward the product are directly assessed. This approach makes it possible for the investigator to identify important attribute characteristics that guide consumer attitudes and behavior (Ajzen, I., 2008).

In a related fashion, the theory of planned behavior provides a conceptual framework that focused on the specific behaviors performed by consumers, be they buying a given brand or product, searching for information about a product, or shopping at a given retail outlet. According to the theory, the immediate antecedent of such behaviors is the intention to perform the behavior in question. Intentions, in turn, are determined by attitudes toward the behavior, subjective norms, and perceived behavioral control. Behavioral, normative, and control beliefs, respectively, provide the basis for the formation of attitudes, subjective norms, and perceptions of behavioral control. As in many other behavioral domains, the theory of planned behavior has proven to be a useful conceptual and methodological framework for the study of consumer behavior (Ajzen, I., 2008).

\section{Research Methodology}

This research is a qualitative research and will be carried out with both primary and secondary data analysis. The primary data will be obtained from diesel automobile consumers about their preference of automobile lubricants. Data collection tool will be a questionnaire. Also data will be collected from the PSO, Shell and Chevron management with their Lubricants team members to know their perception about the market.

The secondary research will be carried out through different newspaper supplements on lubricants, journals, related studies on consumer behaviour and attitude and different online discussion forums. 
In order to gain some initial know-how on the lubricants sector and individual companies in my sample, I had an initial discussion with representatives from these Oil Marketing Companies and as per their input, have found following possible attributes that the consumers consider while buying a lubricant for their vehicle.

- Viscosity / Thickness

- $\quad$ Prior Experiences

- $\quad$ Conveniences

- $\quad$ Pricing

- $\quad$ Long Lasting / Better mileage

- Inspirations by Advertisement

Hence, my questionnaire (see Appendix A) is based on these possible attributes to evaluate consumer attitude towards automobile lubricants.

\section{Sampling}

A sample size of 120 diesel automobile users in total was chosen from different parts of Karachi for this study. Lubricant Brands under consideration will be from three most well known Oil Marketing Companies (OMCs) i.e. PSO, Shell and Chevron. 120 Diesel Engine Consumers include:

Heavy Duty Engines

- $\quad 30$ Trucks

- 30 Buses, and

- 60 Diesel Engine Passenger Cars

\section{Problem Statement}

With the background discussed briefly in the above section, it clearly shows that PSO has the largest retail network followed by Shell and then Chevron. These retail networks act as a good medium for Lubricant sales for such companies, including distributors or the high street selling and then active or direct sales. Keeping such facts in mind, I derived following problem statement:

"To find out the reasons behind the fact that despite PSO having huge retail network as compared to other OMCs, still PSO's diesel engine lubricants are not able to gain a good market share." 


\section{Research Objectives}

This study entails high significance as organizations involved in this business would know the current consumer insight in a neutral manner. The basic objectives of this research are to find out:

- $\quad$ the motivation that drives a diesel engine consumer towards buying a particular automobile lubricant.

- $\quad$ if the advertisement and other BTL activities influence buying decision of a consumer.

- $\quad$ the role of word of mouth behind consumer buying behavior.

\section{Significance of the Study}

This research has a significant importance, as no such research has yet been conducted on consumer attitude towards automobile lubricants in Pakistan's perspective. Secondly, as per the Pakistan Oil Report 2008-09, we have seen the decrease in sales of PSO lubricants, especially in HDEO (Heavy Duty Engine Oil) area. The PSO management in March 2010 made public that the company will revamp its marketing strategy for PSO lubricants as they see lubricants as a profitable area to earn more revenue. This study, at this point in time has a significant importance for the corporate sector to know consumer insight and for the academia to create it as a starting point for upcoming researchers in the lubricants market.

\section{Pakistan Automobile Lubricant Industry: An Overview}

Heavy Duty Engine Oil (HDEO) and Industrial Oil are the top two selling lubricant varieties which jointly contribute for around $65 \%$ of the total lubricant sales. The overall industry includes major Oil Marketing Companies as well as local toll blending plants and lubricants imported from different countries.

Particularly speaking of selling automobile lubricants, there are three major areas of sales i.e. Oil Marketing Companies Retail Network, Distribution outlets or the high-street sales and dealership network. Amongst these three, some Oil Marketing Companies having a huge retail network try to use their outlets as convenience centers for selling their brand. There are four major oil marketing companies operating in urban and rural areas of Pakistan. They are: Pakistan State Oil (PSO), Shell Pakistan Limited (SPL), Chevron Pakistan Limited (CPL) and TOTAL PARCO Pakistan Limited (TPPL).

PSO offers a range of automobile lubricants. Currently PSO Lubricants hold $14.12 \%$ market share among OMCs. There has been a lack of focus on Lubricants as PSO being a market leader in the Fuel business with 3,620 retail outlets, the company's main focus was not Lubricants. Additionally the market maintained or captured by the PSO for Castrol grade was lost after Castrol departed with PSO after more than 36 years relationship. DEO \& Carient were launched in 2003-2004 with a focus to meet the petrol, 
diesel and motorists consumers' requirements.

Chevron Pakistan Limited (Formerly known as Caltex Oil Pakistan Limited) has operated in the sub-continent since 1938. The company's retail network consists of 598 outlets located throughout the country as well as a wide spread distributor network catering to the demands of the Industrial, as well as the Agricultural sectors. The use of Chevron Pakistan Automobile Lubricants has been prevalent since the very inception of the country itself and people in Pakistan have developed a somewhat emotional attachment towards the product. Chevron offers Havoline for petrol engines and Delo for the Diesel Engine consumers. According to the Oil Companies Advisory Committee's (OCAC) report for 2008-09, the company's current market share is $16.17 \%$.

Shell Pakistan operates with a retail network of almost 1200 . The company also offers automotive lubricants apart from the industrial lubricants. These include Rimula for the heavy duty engines, Helix for the Diesel and Petrol passenger cars (same brand name with different grades and classifications that separates the Diesel engine lubricant from Petrol) and Advance for the motorcycles. These brands are almost 45-50 years old brands in the country. Shell positions its lubricants strategically in Pakistan, whereby every ATL activity is followed by a similar BTL activity which helps increase sales of its Lubricants in the country. According to the Oil Companies Advisory Committee's (OCAC) report for 200809 , the company has majority of market share in lubricants sector.

\section{Data Analysis and Findings}

In order to analyze the problem statement, research objectives, and prove the subsequent hypothesis, the research was carried out in the manner as discussed in the research methodology. A total number of 120 Diesels Automobile users were taken under the study whereby properly segmenting the total amount of respondents' i.e.

120 Diesel Engine Consumers include:

Heavy Duty Engines

30 Trucks

30 Buses, and

60 Diesel Engine Passenger Cars

The lubricants under study were from three most reputed Oil Marketing Companies i.e. PSO, Shell and Chevron since they are the top three selling lubricant brands in Pakistan as per Pakistan Oil Report. The questionnaire was designed around some of the key attributes as discussed in the Research Methodology and a few additional in order to know the answers to the research objectives. 


\section{Analysis by Brand}

After the research, a total number of $17 \%$ respondents opted for PSO's brand, while $33 \%$ respondents selected Shell's brand, $45 \%$ selected Caltex brand and $4 \%$ selected other brands like TOTAL and ZIC. If broken into preference as per the categories, following were the observations.

\begin{tabular}{|c|c|c|c|c|}
\hline & Trucks & Buses & Passenger Cars & Total Responses in \% \\
\hline Deo by PSO & $13 \%$ & $16 \%$ & $20 \%$ & $17 \%$ \\
\hline Rimula by Shell & $30 \%$ & $23 \%$ & $40 \%$ & $33 \%$ \\
\hline Delo by Chevron & $56 \%$ & $53 \%$ & $35 \%$ & $45 \%$ \\
\hline Others & & $6 \%$ & $5 \%$ & $5 \%$ \\
\hline
\end{tabular}

- $\quad$ The above overall percentage shows that the respondents mostly preferred Delo by Caltex, followed by Shell and then PSO.

- $\quad$ As per the category wise analysis, it was observed that majority of the truck users preferred Delo by Caltex, followed by Rimula by Shell and Deo by PSO. Whereas, Bus users also followed the same pattern where only $6 \%$ respondents were basically users of other brands like Total and ZIC.

- However, passenger car respondents showed a different behaviour whereby maximum respondents used Rimula, followed by Delo and then Deo. Only 5\% consumers were using other brands of which Total is available on TOTAL retail outlet and ZIC is basically sold on high-streets.

- In the following section, we will discuss the different consumer attitudes with reference to the identified attributes on each brand of lubricant.

\section{Analysis on DEO Respondents}

- The total numbers of respondents for Deo by PSO were: Truck respondents $13 \%$, Buses 16\%, and Passenger Cars were $20 \%$.

- $\quad$ As per the findings, Deo is purchased by the truck and bus owners due to its Viscosity / thickness, prior experience, convenience, pricing and long lasting / better mileage. For passenger car owners, it is the Viscosity / thickness, convenience, pricing (for some respondents) and long lasting / better mileage. As per the respondents, the other factor for passenger car owners was supporting a local lubricant brand due to nationalistic approach. Hence, convenience and pricing are an edge that DEO enjoys today and can be used strategically to increase sales. 
- $\quad$ However, the reason behind the lowest ratings as compared to the other brands in this study was due to the fact that the lubricant is quite new in the market. And people have yet not created a brand sense for Deo since it was launched in 2002-03 while others have been in the market since decades.

- As per their observations, Deo has a good level of viscosity of thickness whereby constituting as one of the basic reasons for selecting Deo, since almost above $60 \%$ agreement was seen by all the categories when asked about the viscosity of Deo.

- Approximately $50 \%$ of the Deo respondents showed their positivity towards repeat purchase of the same brand. The reason for this ambiguous rate is that the consumers are still in a phase of testing the product to know the actual performance and develop an attitude for it.

- One of the basic reasons for opting Deo by all the categories was that it was referred by someone they trusted.

\section{Analysis on RIMULA Respondents}

- $\quad$ For Rimula, the truck and bus owners have shown a positive attitude towards Viscosity / thickness, prior experience and long lasting / better mileage. For them, pricing and convenience does not matter. The same is the case for the passenger car owners.

- However, approximately $70 \%$ of the Rimula respondents of the passenger cars showed a positive attitude towards Shell advertisements and promotional activities. Since Shell changes its advertisements at almost every 3-4 years, following the upgraded version of the previous theme, backed by similar promotional activities, it becomes obvious as to why $40 \%$ i.e. maximum number of respondents have shown a positive attitude towards Shell lubricants. However, still, advertisements are not the primary reason for the respondents to choose the Rimula. "It is the better mileage and performance that counts", quoted by one of the passenger car respondents.

- $\quad$ One of the reasons for choosing Rimula was word of mouth. Someone the respondents trusted advised them to use Shell lubricants and till date they are using it. The decision supporters - as per the respondents' comments - were their close family members whom they trusted on vehicle related advices and their mechanics, who suggests what is good for their vehicle. Approximately $70 \%$ of bus and truck respondents have shown a positive attitude towards the lubricant being referred at one point in time to them by their elders; close family members etc. that has now converted in prior experience. 


\section{Analysis on DELO Respondents}

- $\quad$ For Delo, all the three categories have shown the major attributes used for opting Delo is Viscosity / thickness, prior experience and long lasting / better mileage.

- $\quad$ Delo users were not attracted by the advertisements and promotional campaigns. Rather they were already loyal to their brand due to its strong core propositions. Hence, Chevron advertisements do not play a major role in consumer purchase decision.

- $\quad$ All the respondents have shown a positive attitude towards word-of-mouth. This was done not today, rather a long time back through their father, cousins etc. The reference of Delo has now become a prior experience for the consumers. Delo being the oldest brand takes an edge on complete consumer retention due to being the oldest brand and have performed with consistent quality.

- $\quad$ Many of the Truck and Bus respondents said, "Hum Shuru say yehi istamaal kar rahay hain - meaning - we've been using Delo since very long time."

- $\quad$ Delo as compared to other brands costs higher followed by Rimula and Deo. But consumers who opt for Delo do not consider price as the primary factor to choose a lubricant.

\section{Findings in the Light of Research Objectives}

The research questions as discussed in the beginning of the report were the important pillars in conducting the research. Following were the observations:

\section{Motivation that drives a Consumer towards Buying a particular Automobile Lubricant}

- While conducting the research it was found that the most important attributes that count as the motivation for the respondents to buy a lubricant were the viscosity / thickness of the lubricant, long lasting / better mileage and prior experience of the brand.

\section{Influence of Advertisements and other BTL Activities in Buying Decision of a Consumer}

- It can be concluded that it is the Viscosity / thickness, prior experience and long lasting / better mileage that counts as the major factor in consumer purchase decision. Advertisement and promotional campaigns play a role as a short term strategy to increase sales for a limited period of time.

- $\quad$ PSO, Chevron and Shell consumers do not make their purchase decision based on advertisements and promotional activities. Only $40 \%$ out of passenger car respondents for Shell showed positive attitude towards advertisements. It can be noted that Shell advertisements have been quite effective as compared to 
PSO and Chevron.

\section{The Role of Word of Mouth behind Consumer Buying Behavior}

- $\quad$ The reference from a trustworthy person who plays a role in the decision support is also an important factor in lubricant purchase behavior. The findings and observations suggest that for DEO consumers, it was the role of a trustworthy person that played an important role in buying decision, since DEO is relatively new in market. These included fellow truck and bus owners, a mechanic, a friend who had a prior experience with DEO etc.

- $\quad$ Approximately $70 \%$ truck and bus owners out of Shell Lubricant respondents showed a positive attitude towards being referred by their cousins, fellow truck and bus owners and even oil changing mechanic who suggested quite some time back and that became a prior experience for the consumer.

- $\quad$ The passenger car owners of Shell Lubricants didn't require any reference since viscosity / thickness of the lubricant, long lasting / better mileage and prior experience added to their purchase decision more than any reference.

- As for Chevron, all the respondents have shown a positive attitude towards wordof-mouth. This was done not today, rather a long time back through their father, cousins etc. The old reference of Delo has now become a prior experience for the consumers.

\section{Conclusion}

- $\quad$ As per the problem statement, it has been observed that the PSO lubricants are performing well as per the basic attributes on which the respondents for PSO lubricants were evaluated i.e. Viscosity / thickness, prior experience and long lasting / better mileage.

- $\quad$ These attributes count in the major decision making by the consumers on which the Deo performs well.

- Hence, after a thorough analysis it is seen that since PSO's diesel engine lubricant brand is new in the market i.e. it was launched in the year 2002-03, consumers have yet not developed the complete experience of the brand.

- $\quad$ Comparing DEO with the other performing brands in the market, they are quite older. As per the observations, Delo by Caltex have been in the market since the inception of Pakistan. The brand name has remained the same, only the packaging was upgraded from time to time.

- It is also found that the consumers using PSO's Deo brand, are quite satisfied with it's attributes, however, when it comes to repurchase, respondents became neutral, whereby stating that they needed some more time to evaluate the brand's 
- As discussed in the findings, it may be concluded that it is the Viscosity / thickness, prior experience and long lasting / better mileage that counts as the major factor in consumer purchase decision. Advertisement and promotional campaigns play a role as a short term strategy to increase sales for a limited period of time.

\section{Recommendation}

As discussed in the conclusion above, that it is the Viscosity / thickness, prior experience and long lasting / better mileage that count as major factors in consumer purchase decision. However, In addition to these attributes, PSO lubricant consumers are also attracted to Deo due to its attractive pricing and convenience / availability, which is a unique selling proposition (USP). This USP can be capitalized as an edge over other lubricants. It is advised that PSO should develop a brand image development of its lubricants by creating proper attire of the brand by all means of communication. This will help consumers to easily have a brand recall like they have for other lubricants. Also, In order to make advertisements effective, Shell's strategy can be followed whereby a long term theme with strategic approach should be used to increase positive brand perception.

\section{Research Limitations}

- No local research was available till date to create an initial point of start.

- It was difficult to find a lot of Diesel Engine Passenger Car owners

- It is difficult to communicate with the truck and bus owners, who constitute the highest consumption of HDEO. Since they mostly belong to the rural areas, it became almost impossible at times to communicate even in Urdu, as they spoke their regional languages only.

- $\quad$ High-Street Sales is a difficult and unstructured market; hence it was not included and is difficult to record the consumption patterns.

\section{Areas of Further Research}

- $\quad$ Consumption patterns of Petrol, CNG and Motor oil lubricants can also be a good area of further study.

- $\quad$ Recording the consumption pattern for high street sales can be a challenging area to explore since no such study is done as yet on academic level.

- $\quad$ Exploring mediums of communication of the truck and bus owners can also add to a good area of research to find out ways of communicating brand image of lubricants to this segment. 


\section{References}

Ajzen, I. (2008). Consumer attitudes and behavior. In C. P. Haugtvedt, P. M. Herr \& F. R. Cardes (Eds.), Handbook of Consumer Psychology, New York: Lawrence Erlbaum Associates, pp. 525- 548.

Armstrong, G., Kotler, P. (2000), Marketing, 5th ed., Prentice-Hall, NJ, pp.153-4.

Ajzen, I. (1988). Attitudes, personality and behavior. Milton Keynes, London: Open University Press.

Ajzen, I. (1991). The theory of planned behavior. Organizational Behavior and Human Decision Processes, Vol. 50, pp. 179-211.

Armitage, C. J., \& Conner, M. (2001). Efficacy of the theory of planned behavior: A meta- analytic review. British Journal of Social Psychology, Vol. 40, pp. 471-499.

All About Oil, (2009), Retrieved on April 2010, from

http://www.castrol.com/castrol/genericarticle.do?categoryld=8264018\&contentld=7007302

Cohen, J. (1992). A power primer. Psychological Bulletin, 112, pp. 155-159.

Caltex History (2010), Retrieved from Caltex Official Website http://www.caltex.com/pk/en/history.asp

Caltex Lubricants (2010), Retrieved from Caltex Official Website http://www.caltex.com/pk/en/lubricants.asp

Diverse Sense (2008), Retrieved on April 2010, from http://www.driversense.com/driversense/column/264

Fishbein, M., \& Ajzen, I. (1975). Belief attitude, intention and behavior: An introduction to theory and research. Reading, MA: Addison-Wesley.

Godin, G., \& Kok, G. (1996). The theory of planned behavior: A review of its applications to health related behaviors. American Journal of Health Promotion, Vol. 11, pp. 87-98.

Heavy Duty Diesel Engine Oils (2010), Retrieved from Caltex official website http://www.caltex.com/pk/en/Lubricants_HeavyDuty.asp

Leon G. Schiffman, Leslie Lazar Kanuk (1999), "Consumer Behaviour”, 6th Edition, Prentice Hall, New Delhi

Neal, Quester, Hawkins, (2002). "Consumer Behavior, third edition," p. 4. Neal Quester Hawkins (2002), "Consumer Behavior - Implications of Marketing Strategies", 3rd Edition, Mc Graw Hill Irwin.

Journal of Independent Studies and Research - MSSE

Volume 9

Number 1

January 201144 
Pakistan Oil Report (2007-08), Published by the Oil Companies Advisory Committee (OCAC)

Pakistan Oil Report (2008-09), Published by the Oil Companies Advisory Committee (OCAC)

PSO, Business at a Glance (2010), Retrieved from PSO's Official Website http://www.psopk.com/about_us/business_glance.php

Roger Blackwell, Clare D'Souza, Mehdi Taghian, Paul Miniard, James Engel, (2007), "Consumer Behaviour: An Asia Pacific Approach", Thomson.

Shell in Pakistan (2010), Retrieved from Shell's Official Website http://www.shell.com.pk/home/content/pak/aboutshell/at_a_glance/ 